\title{
A Response to Johanne Kübler's A Review of Zeynep Tufekci - Twitter and Tear Gas: The Power and Fragility of Networked Protest (2017, New Haven: Yale University Press)
}

\author{
Zeynep Tufekci ${ }^{1}$
}

Published online: 27 July 2019

C) Springer Science+Business Media, LLC, part of Springer Nature 2019

It's been eight years since the Arab Spring burst onto the scene, and a little more than that for Occupy - the global movement against inequality that witnessed biggest protests in history, coordinated with only a few weeks' notice. The protests in Tahrir Square, Cairo, were among the biggest in Egyptian history. According to estimates, about a third of Bahrain's total citizens turned to the streets in protest - a staggeringly high number. It was country after country, and it was a historic turning point for the region and for the world by almost any measure. On Twitter, after the Tunisian autocrat fled the country, the protesting youth playfully teased Egyptians if they could be next in ousting their dictator.

It was clear from the first moment of the so-called Arab Spring were intertwined with technological changes that were taking place - a few young companies like Twitter and Facebook, plus all the tools of digital connectivity: smartphones in many hands. In fact, the defining photograph from that era is perhaps a young protesters with smartphones, perhaps taking selfies or livestreaming at a protest. My book, Twitter and Tear Gas: The Power and Fragility of Networked Protest, which Johanne Kuebler kindly reviews in this issue, was mostly written between 2013 and 2016: slightly after the optimism that surrounded the initial year of the uprisings that swept the world faded but not that long after; and also when the longterm impacts of said events remained unclear. Despite uncertainties, I felt that there was enough to layout a conceptual case for how social movements - especially large-scale protests - differ from their counterparts inprevious eras; laying out a theoretical framework for interpreting the power and role of protests as well.

The central thesis of my book wasn't that these protests - the Arab Spring, Occupy Indignados in Europe-were necessarily successful or not, but that they were different creatures compared with protests of yesteryear.

This reply refers to the comment available at: https://doi.org/10.1007/s10767-019-9316-3.

Zeynep Tufekci

Zeynep@unc.edu; zeynep@technosociology.org 
In the past, it took years- sometimes decades- to organize a protest. The protest's event was the culmination of that lengthy process - an exclamation mark at the end of a long sentence. Nowadays, a big protest is the beginning of the sentence, the first letter. That's a very different dynamic.

The March on Washington in 1963 was conceived more than a decade earlier and maybe took almost two decades from conception to execution, by certain counts. It took all those years to build a movement that could hold and sustain the momentum for that march, and pull off the complicated, difficult and even dangerous logistics:hundreds of thousands of people had to be transported out of Washington DC the same day, as it was not safe for people campaigning against racial inequality to stay in the district. By the time the day had come and gone, an impressive undertaking had been completed successfully. Just the logistics of the march had taken six painstaking months of work: index cards, files, paper.

Occupy started with an email and happened in a few months. It started in New York, but it quickly spread elsewhere. The global protest took only two weeks from conception to execution - and it was the biggest protest, to date. This pattern has been repeating itself. After the election of Donald Trump in 2016, a few people put together a Facebook group to organize a protest the day after his inauguration. It was called the Women's March, and it wasn't just in Washington DC - it was held in dozens of cities around the country; and it was the largest march in the history of the USA. Just the DC section of the Women's March ended up with more than a million rides on the subway system - second only to the inauguration of President Barack Obama.

As Kuebler recounts, I theorized that this reconfiguration of protest movements - the big March first, then the movement organization — was enabled by affordances of digital technology. New tools made connecting, organizing and handling logistics much easier, compared to the index cards that the organizers of the March on Washington had labored over for six months back in the sixties.

However, despite differences in the organizational trajectory, the moment of the protest feels the same. It was, as it has always been (as I discuss in many chapters in the book), a moment for a community to come together and draw strength from each other. It's energizing and fulfilling. But where does the moment draw its power to enact change? When protesters chant "The Whole World is Watching," what do they expect from that? Indeed, nowadays, it's quite possible the whole world is watching; but when does it matter and when does it fade? Why would it empower a movement to get nearer its goals if the world was watching versus if it were successfully censored?

This is where my book theorizes more broadly about protests and social movements: I argue that besides being a gathering place for participants, protests are where movements signal their underlying capacities to people in power. A protest that's large and well-organized signifies a large number of people who are not only upset, but upset enough to take to the streets. It also signifies a certain amount of organizational capacity: look what we can pull together. But the difference between the digital and pre-digital era changes what that underlying organizational capacity displayed by the protest corresponds to. It's not that the main dynamics of a protest signifying underlying capacity are different, but the same event may not point to the same kind of logistic and other capacities simply because it's easier. Similarly, a protest under conditions of repression signifies a lot more than a protest in a democratic country where the participants are not necessarily putting their lives or livelihoods on the line. Consequently, if digital technology can act like an amplifier and a tool for organizing logistics 
easily — Facebook groups! Twitter hashtags! Excel spreadsheets! - a protest in the 21st century itself no longer signifies the same underlying power as a protest of yesteryear.

This changed trajectory also means that large-scale movements enter into their first challenging moment without a lot of infrastructure; since they are responding immediately to the initial event: the protest. For the Arab Spring countries, where the movements immediately met massive suppression (often at the hands of militaries), this meant tragic consequences. Unlike the aging autocrat Hosni Mubarak who panicked at the sight of protesting Facebook pages and clumsily tried to shut down the internet, the presiding Egyptian army decided that it was going to join the digital field as well. It issued its very first communique on its Facebook page, and continued to other platforms. Pretty soon, Twitter was no longer the place where dissidents found one another and chatted freely. Instead, they were faced with harassment and trolling both from agents of the government and from the mobs instigated by them. The online world became hostile and even dangerous for activists: they were jailed, forced into exile and/or worse.

Kuebler's review also addresses the theory of digital technology and censorship as it now works in the 21st century, which was in one of my book's chapters, which discussed how governments struck back against digital tools. Since the writing of these chapters, governments' methods have only spread further and have become part of the standard repressive toolkit around the world. Governments found that even though they could no longer sever the link between information and the people (because digital technologies had obliterated the old means of censorship when silencing or pressuring a few gatekeepers) they still could sever the link between information and action by making information unactionable; by drowning it in competing narratives, by creating distractions that made it difficult for dissidents to focus attention, by challenging the credibility of claims. In a cloud of confusion, facts do not have the same power to move people to action. All over the world, this has become almost a standard operating procedure of authoritarians.

This is also why I wrote heavily about the business models and algorithms that are used by the leading social platforms, because these governments and platforms interact. There is a chapter that is dedicated to the specifics of this as well as a chapter dedicated to the theory of technology, affordances and society along with numerous examples throughout the book.

During the years that I wrote the book, this relationship was already visible. Since then, it has become an overwhelming topic, with daily calls for regulation or de-monopolization. The activists also drew my attention. There were few groups as sensitive to these social platforms' business models and algorithms as the activists who strove for attention through these platforms.

In the book, I theorize at length about 'attention,' a concept that has been under-examined in scholarship, or sequestered to mass media studies - something that was more reasonable when public attention basically meant 'mass media' practically held a monopoly on attention. Politics occurs in the space of sustained attention, and it is thus a crucial resource for all actors; and social movement actors have long strategized for getting attention to their cause (which, incidentally, used to be another important function of protests that has now become more diffuse). A range of strategies were employed by the dissidents; including stunts, NGOs, protests at media outlets, 'alternative media' and more. However, with the rise of social media, all of a sudden, activists could command attention immediately, at mass scale, without the approval or participation of traditional gatekeepers. But they are now subject to the new gatekeepers' structures: their algorithms, affordances, functions. As such, activists and 
dissidents that I met around the world were extremely sensitive to how Facebook's newsfeed algorithm worked, or how Twitter's 'trending topics' picked the 'winners.'newapos; Even slightest changes would be detected by them, often, before the change became public knowledge.

While the new gatekeepers were structured differently and allowed dissidents to reach masses rather immediately, their ad-financed business model created a large number of challenges and distortions for social movements, and for society. Information flows have become increasingly individualized and differentiated. Social media giants made their money by deeply surveilling their users and then using that information to customize content to (1) keep users on the platform for longer (2) advertize to them and (3) research for future design decisions. Thus, social media giants are favorable ground for things that could go viral; and that includes outrage, feelings of unity and polarization between outraged, united groups. (Politics became even more of a sport where fans of one teams shouted at the other.)

Authoritarians around the world quickly realized how to use this business model to their advantage. First, outrage and polarization can be used to drown out dissidents. Second, microtargeting (e.g., via Facebook) can function as a powerful tool for spreading precise misinformation and/or harassment. Facebook was often too ready to comply; offering, for example, Philippine's strongman Rodrigo Duterte's "white glove" treatment in return for Duterte's advertising payment(s) (according to press reports).

My book was finalized during the 2016 election campaign in the USA, which later erupted into a scandal surrounding Facebook and the misinformation that went viral on the platform. But Facebook also affected the 2016 elections even by playing by 'the rules.' For example, in an interview with Bloomberg, Trump's digital-campaign manager Brad Parscale stated that the team had launched a "voter suppression" effort through Facebook where they targeted AfricanAmerican men in Philadelphia and/or Haitians in Florida with messages that tried to dissuade them from voting; attempting to convince them both parties were equally bad, or that elections just weren't worth participating in. He also said how Facebook only allowed the pretargeted people to receive this message - therefore avoiding a potential counter campaign trying to refute the argument; unlike the era of television where we would have a chance to see what was being said. Even direct mail, less public than television, could easily end up in the hands of the opposing candidate unlike a fleeting message on Facebook. Indeed, if Brad Parscale had not given that interview, the public would've never known. Scholars have also documented how Facebook embedded staff with Donald Trump's beleaguered campaign to help them better spend their money on the platform, thus compensating against the organizational weaknesses of his surprise candidacy. ${ }^{1}$ Facebook also acted as a great amplifier for misinformation and fake news; a claim that remains under-researched to this day, because important data is locked up within the corporation, and misinformation was distributed personal screen by personal screen.. Unlike the mass media era, we have communication that is at once mass but not public, and thus hard to refute or research.

So where do things stand now? There is no one answer. For the social movements outlined in the book, the outcome has-so far-been bleak. Many countries lay in tatters, their dissidents crushed, their politics suffocated. Yet, there has been growing awareness on the intersection between the ad-financed business models and authoritarianism. Facebook, Twitter

\footnotetext{
${ }^{1}$ Kreiss, D., and S. C. McGregor. 2018. Technology firmsshape political communication: The work of microsoft,Facebook, Twitter, and google with campaigns during the2016 U.S. presidential cycle. Political Communication 35(2):155-77. doi: 10.1080/10584609.2017.1364814
} 
and Google executives have been called to testify in the USA: Congress and Europe enacted privacy legislations. There may be some forthcoming changes to the platforms; and the runaway surveillance may be curbed by legislation, user disgust and new technologies.

In the meantime, these technologies still empower all sorts of groups: sympathetic ones like the Egyptian dissidents, but also white supremacists and religious extremists. The challenge will be to take a human rights framework - the values that exist in documents and jurisprudence and apply them to these technologies, shaping innovation in the human rightsconscious direction. That remains an open challenge; and it is how I had ended my book that Dr. Kuebler has so kindly responded to. This is the time toask questions. History moves on, along with a political, complex and consequential process about the technologies that help shape our world.

Publisher's Note Springer Nature remains neutral with regard to jurisdictional claims in published maps and institutional affiliations. 